\title{
Strategic Culture: The Facets of Foreign Policy and National Security
}

\author{
BENEDEK Márta ${ }^{1}$
}

\begin{abstract}
The Hungarian foreign policy and strategic policy have gone through radical changes in the past twenty-five years. It has deepened since the beginning of the $21^{\text {st }}$ century with the shifts in international politics being on the agenda. There is a new political viewpoint emerging which involves a new philosophy on internation-al security, describing it as being an attribute of the strategic thinking for solving the international crises by bringing forward the re-evaluation of national security. The scope of this paper is to present the changes that occurred on the strategic lev-el, concerning national security, embedded in the strategic culture, which emerge from the transforming foreign and security politics.
\end{abstract}

Keywords: strategy, strategic culture, foreign policy, security policy, national security

\section{Introduction: Trends in the $21^{\text {st }}$ Century}

After the turn of the millennium there have been in-depth economic, political and social chang- es on the international stage of which only part had been foreseeable. Globalization and the system of mutual interdependence have gotten stronger. The non-western, mainly Asian soci- eties have established their own economic potential and on that basis they have built their new military capability. The wars fought against Islamic terrorism have gained new impetus and new, radical actors have appeared on stage. The number of collapsing, weak states has multi- plied. Contagious diseases and pandemic illnesses have multiplied, and the world economy, world politics and security are aligning themselves along new paths as a consequence. The pre- vious trends have been crushed under the new circumstances created by the shifts, uncertainty grows, instability intensifies and new, unexpected events come up. There have always been great, pivotal changes that gave new directions and turned the flow of history over the long run, qualitatively transforming societies. All the segments of the social and economic structure have changed, from the techno structures, through the institutions, to the ruling principles.

Today's techno structure is composed of information technology and communication techniques. Being in strong interaction with them, the structures of the economy are un- dergoing transformation. The revolution of the information and communication techniques interlocks with the development of a knowledge based society, which is characterized by a postindustrial structure. [1]

In the light of these changes we can state that thinking about the future has become an everyday activity and scientific planning has become indispensable, embodied by a mid and

1 e-mail: benedekm18@gmail.com 
long term strategic scheme. In terms of individual states, the definition of new security policy goals has become necessary, and so has the assignment of the necessary instruments, while both assets have to rest on reality and must be feasible regardless of the changes in the inter- national circumstances.

The scope is not as much the precise forecast of the future, but "to help the decision-mak-ers outline the future, change the leaders' behavior and break the suffocating shell of stereo-types, by the means of which more cautious decisions can be made, and a greater flexibility can be achieved for a state or an organization to face the challenges of the future." [2: 36]

\section{Strategy and Strategic Culture}

"Strategy" originally is a Greek-Latin common expression from the domain of the military. Its use is linked to activities concerning commanding armies and initially it denoted the art of winning a war, specifically of leading, moving, positioning and supplying the armies. Essentially, considering its core and aim, it did not mean the struggle for total destruction of the enemy by all means, but the struggle to achieve victory. In the professional periodicals of the 1960s it was only sporadically used, but from the 1980s the word "strategy" was predom- inantly used in other contexts than the military. Its use became widespread in the domain of economic and political life, in culture, and in relation to several social phenomena as well.

In Liddell Hart's description "strategy" is no other than the employment of the military forces and tools for political purposes. André Beauffre has a similar opinion when he speaks about "the art of employing military forces for political purposes." [3: 24-25] Samuel Hun- tington's definition of strategy comes from the idea that "the specific objectives of the polit- ical leadership" rests on a certain premise. Namely, that the creation of strategy happens at the highest political decision-making level, tracing the main objectives and tasks that pertain to all institutions and organs of an individual state, among them, armies. [4] The starting moment for all strategies is an anticipatory vision of the future, a kind of forecast, which of course, not being foreseeable, and prone to be influenced by the unexpected, cannot be accu- rate. In concordance with the vision of the future values and sets of interests can be delineated and also can be the external set of conditions, that is, the possibilities, the threats and dangers which precede the call for taking measures. [5: 20] We also consider a part of the process the materialization of the goal itself and the evaluation itself, in unison with the definition of "strategy" and with the ability of giving reactions and making modifications as responses to the circumstantial uncertainties. The first and foremost component of strategy is the princi- pal, or the political one. It outlines the essential values and interests of the state and defines the instruments, techniques and conditions on which the goals can be achieved. It entails the need to formulate or define the dangers that threaten those values and interests, too.

In relation to the circumstances, when strategies are designed, the ensuring of relevance and coherence is a basic requirement. Relevance is the criteria which involves that only those factors and tendencies should be taken into account which are among the circumstantial ele- ments and are related to the values represented. Coherence is the synthesis of the circumstan- tial factors and processes, that is, those activities, which are priorities for the country and with which the state can and is willing to cope. The interests give answer to the question of why a strategy is needed, the circumstances to where that strategy has to be implemented or carried out. [6] Similarly important is the time factor, as the strategy outline is a process going on in 
the present, while analyzing, drafting and anticipating the aspects of the future, in the light of past events, are the factors of continuity.

By its nature, strategy is twinned to forecasting and it is aimed at the formulation of the method for a future activity, moreover, it is linked to interrelated social and natural process- es forming huge, complex systems. Twisting the definition, we get "stories" of the future, through which we can recognize the ever changing details of our environment and thus we can exploit them.

Given the purposefulness of the strategy, its relationship with the future can be defined within the framework of the interdependence of vision and forecasting. According to a wide- ly accepted concept, the vision of the future coincides with the system of strategic targets; in other words, with the distant condition for the achievement of which they want to employ the strategy. In this case one may regard the strategy as the main part of the vision, which is the difference between the present situation and the desired situation. From another perspective, the vision of the future is linked to the strategy through interests and circumstances influ- enced by the vision of the actor, who in our case is the decisionmaker.

\section{Strategic Culture}

The present day strategy has to be built upon the interests and circumstances developed with- in the network of the present and past impacts. It has to be an organic part of the strategic culture. The definition of "strategic culture" is as multicolored and multi-layered as that of "strategy" itself.

As Jack Snyder put it, it is a sum total of ideals, supposed emotional responses and fixed habits that characterize a national strategic community that have been acquired either through education or through following previous role patterns. [7: 9] According to Snyder, the stra- tegic culture fundamentally influences the strategic decision-making and the notional frame- work of a strategic discussion. Ken Booth says that the strategic culture has an impact on what the rapport between two individual states is in the light of security issues. In his opinion, the notion encompasses the traditions, the customs, the set of values, the behavioral patterns, the symbols and the actions of a nation, its adaptability to the circumstances and also the problem solving methods in cases of military threats and the employment of the army. A. M. Johnson describes strategic culture as a result of a socialization process in which the de- cision-makers exert influence on the different strategic approaches and processes and at the same time, they modify them. [8]

Longhurst's formulation of strategic culture states that it is a summarization of constant views, opinions, standpoints and the practical processes of employing the military which are implemented within a long period of time and which are typical of a certain nation. Accord- ingly, Longhurst attributes great significance to the decision making power and the actions of the elite, because it is the elite which defines the strategic objectives and accepts the important decisions. He adds that the negative events have a strong influence on the strategic culture as a result of which the strategic culture may undergo certain changes. "The logic of strategic cul- ture then, resides in the central belief that collective ideas and values about the use of force are important constitutive factors in the design and execution of states' security policies." [9: 7]

Monica Garuip joins Longhurst when defining strategic culture as the sum of all the instruments guaranteeing security. [10: 41] 
At present the most accepted use of the term, strategic cultures, beyond its reading in the military sense and by having become a political definition, is that it is a kind of measurement for the effective security politics to face new challenges, threats and even cooperative needs. It seeks for answers to questions like what vision of security stands at the base of the security policy of the individual states, which are the common norms, ideals and convictions that outline the security policy and defense goals in a society and define the forms of action. It is the state or goverment itself that defines which are the factors that endanger its security, or in other words, its strategic environment, and how, and with what instruments or forces can it act against them.

The definition does not relate only to the cases of the individual states, but also to the level of the international communities, regarding the new kinds of challenges and threats and regarding the requisites for cooperation and duties. It gives the guidelines for an effec- tive security policy. The European Security Strategy accepted by the European Council in December 2003 seems to support that, by stating as an objective the following: "We need to develop a strategic culture that fosters early, rapid, and when necessary, robust intervention" for Europe as a global actor standing on an international order, and based on effective mul- tilateralism. [11] The notion is also used in NATO terminology, which relates to collective defense, the cooperative security, crisis management and common actions of key importance, emphasizing the importance of the strategic partnership with the EU. According to Alexan- der Siedschlag it is the system in which the military power of the NATO member states is cumulated. [12]

\section{The Transformation of Hungarian Strategic Culture}

Hungarian foreign and security policy has undergone radical changes since the change of regime through the transformation of the basic values and interests, involving the transition from the Warsaw Pact membership to NATO membership, then to full adherence with the Eu- ropean Union, expanding in all respects Hungary's opportunities to action. The country had to define its place, its national interests, and the modes of representing those interests within the framework of a fledgling and constantly changing international security system, which is reflected in the strategic culture and goes along three distinct stages:

$1^{\text {st }}$ period: the end of the Cold War, the dissolution of the bipolar world order, the period of democratic regime change, when the opposition of physically blocked countries, extort- ed to act so by overall military means, dissolved in the region. The geopolitical status of the country changed profoundly in the discussed period. Germany was reunited, the Soviet Union and the disintegration of the Czech-Slovak Republic and Yugoslavia left 22 new in- dividual states behind, and the number of the 5 neighboring countries around Hungary grew to 7, out of which 5 were entirely new. The process of transition brought along the kindling conflict in the Balkans once again.

There emerged a need to set up a new system of strategies and institutions, as the national goals and instruments lying in the middle of the strategic thinking called for a re-definition of the political aims of security policy and the foreign economic policy, close- ly following. Some frameworks have had to be clarified, like the status of the country, its national interests, the ways of representing those interests and moreover, the frames, the character and the size of the international participation. National interests outlined the stra- 
tegic tasks of the internal and external politics of the state which were aligned along the so called three pillar structure:

- the Western integration;

- the placing of neighborhood relations policy on a new basis, that is, regional cooperation;

- then minority rights, first and foremost the enforcement of the rights of the Hungarian ethnic minorities in the neighboring countries. ${ }^{2}$

At the beginning of the process, after the political changes of 1989-1990, several options opened up - though their political reality varied and differed, Soviet troops were still sta- tioned in Hungary until mid-June 1991 and the country was still a Warsaw Pact member. ${ }^{3}$ The only real alternative was the political and military integration with the West. In practice, the country got into a situation in which the old security system did not perform any more and the new one had not started yet, and as a consequence the individual national security policy had to be formulated and devised. The basic principles of security policy and the homeland de- fense of the Hungarian Republic, adopted in 1993, reflect the strategic thinking of the period. They were "products" of a transitional era when the former Soviet doctrines did not prevail any more, but the western way of thinking had already cast a light on them.

$2^{\text {nd }}$ period: reaching Euro-Atlantic integration, whose two important milestones are the accession to NATO in 1999 and to the EU in 2004. In the focus of the tasks accompanying the process were the integration of the various organizations, the effective participation, the efficient assertion of interests and the active cooperation in their renewal. Thus the first pillar of the Hungarian foreign and security policy was set and at the same time the consensus started to crack which originated from the differences along the so called Status Act (concerning ethnic Hungarians living in the neighboring countries). As a re-definition of foreign policy priorities and among the strategic goals we foresee Hungary as a com- petitive country within the EU, a regionally successful Hungary and a country which feels its responsibility for the fate of the world. In the latter role, the country takes part in the international peace and crisis-management operations, and also, Hungary has an active role in the fight against terrorism. [13] In its foreign policy, serving the national interests of the country, Hungary takes part in military operations not as much with its numerical power but with its participation and presence. "So if the country takes an active part in the various tasks and brings good results, it will gain adequate weight and it will have opportunities to benefit the other areas of its interests or to gain the friendship or partnership for supporting its goals." [14] On the level of strategies, the basic security and defense principles - still in

2 When defining the external policy triad, the issue of neighbor policy and the questions related to ethnic Hungarians was both a historic necessity and an interest of the state. The policy of integration, at the same time, was influenced not only by political, but by economic factors as well. The two were connected within the system of the bilateral basic treaties aimed at stabilizing the relations with the neighboring countries and considered to be the conditions for joining the Euro-Atlantic community.

3 Out of these alternatives the possibility of neutrality comes as the strongest feature. The individuality and reliance of self-power was one of the possibilities, though these ideas did not have a real basis even in those times. The possibility of reforming the Warsaw Pact remained alive in common thinking. The idea of NATO membership, as a guarantee for the security of the country came up on 13 Apr,il 1992, in Gyula Horn's (then MP) out-of-agenda speech. Parallel to these aims there appeared the need to bring to life of a new, common, European security system, as well as a constructive Central-European policy, which preferred a model of neighboring countries cooperating tightly in areas like economy, politics, defense and culture - "the Danube community model." 
force - of the Hungarian Republic adopted in 1998 overwrote the act of 1991 and formed the base of the National Security Strategy accepted in 2002, then modified in 2004, and also formed the base of the first National Military Strategy of 2009, and the Foreign Policy strategy in 2008.

$3^{\text {rd }}$ period: the determining and most radical event of the cycle was the global financial and economic crisis of 2008, and the beginnings of the ever strengthening and challenging cyber technology attacks in 2007/2008. ${ }^{4}$ The instability of global space continued expand- ing. ${ }^{5}$ The questions of external and internal stability intertwined with terrorism "strikes" with renewed forces and organized crime and its close companion corruption. Global climate change became a significant factor on the palette of challenges with the fight for freshwater and natural mineral resources, with the fight against the spreading of virulent diseases or the issue of migration.

Meanwhile the environment of security in Europe and Hungary has changed, too. On the one hand, as a positive element, Croatia joined NATO and the European Union, on the other hand, as a negative are the crises in the neighboring regions. The Arab Spring in 2011, set the Middle East on fire, and has left problems and tensions which remain unsolved, to be sure further turmoil is yet to come.

In 2014 the Ukrainian-Russian conflict implied not only a military threat for Hungary, but having an impact on the Hungarian minority policy and on the energy policy and further negative effects on the various segments of economic life. All of these have called for a new wave of revising the strategic goals.

The new political governing cycle wished to signal its start by re-defining public law, embodied by accepting a new constitution, named the Fundamental Law, establishing a new constitutional structure for Hungary and the related system of strategies. The priorities of foreign and security policy have become regional politics, including the protection of the in- terests of the Hungarian ethnic minorities, and the Euro-Atlantic orientation, in other words, representing the national interests in the EU and in NATO. A further priority was the politics of "global opening". This set of viewpoints was somewhat modified in 2014 as summarized below:

1. Issued after the 2011 EU presidency, defined as a document of strategic character "Hungary's Foreign Policy after the EU Presidency" [15] alludes to a value-based and value-driven foreign policy. In other words, the goals are defined along the values, and the government envisions an ideal position that is practicable and consequently, it defines the interests as a road to achieving the objectives. Not only are the instruments paired to the goals, but the goals are paired to the values. In this respect the 2014 foreign policy outlines reflect a new set of views as a contrast. To the expense of the values it prioritizes the Hun- garian interests, which reflect long-term, real-political thinking in perspective, opposing the dominance of the actual group interests of those in power. The point of reference, in this spirit, is not the system of organizations of which Hungary is a member, like the EU or NATO, but the national interests, which come on the top of the community interests, so the

4 The series of attacks against Estonia and Georgia in 2008 cast a light on the ever strengthening role of the information operations and cyberwarfare. The states had to realize what new threat has appeared; with the use of information technologies any information infrastructure can be destabilized and neutralized.

5 Compared to the year 2008, the peace conditions have improved in 51 states, but have deteriorated in 111 states. www.galamuscsoport.hu/tartalom/cikk/390320_vilag_bekemutato_avagy_egyre_dragabb_a_bekesseg (downloaded: 28 01 2015) 
main task of diplomacy is to represent national interests, to which the values attach, with the accent on national interests. $^{6}$

2. In 2014 the responsibilities of foreign policy got enlarged with a new segment, which is the external economy. The foreign political decision-making process in the near future will become external economy focused. Its duty will be to represent Hungarian economic interests. The foreign affairs strategies do not change, but their tools do: in order to expand export, new foreign markets have to be conquered and workplace creating investments have to be attracted. Hungarian businesses have to be supported in their efforts to appear on the international arena. The cornerstones of new foreign policy are fixed on the following:

- new foreign market possibilities have to be secured, export has to be expanded. The aim of government is to make one third of the overall Hungarian export go outside the EU by 2018, meanwhile to make grow or give a new impetus to the eastern opening policy, which is a reflection of the shift of the stress going on in the world economy and change in politics, as a consequence of globalization;

- sub-serving the success of Hungarian businesses abroad, and supporting Hungarian participation in international calls for tender;

- new, workplace creating investments should be attracted and international companies should be convinced about the prosperity of investing in Hungary.

The security policy also has to adapt to the above drafted new foreign policy ambitions, as the changes in the strategic perspectives left the three pillar system of priorities untouched.

\section{Implications on the national security services}

The national security policy is an organic part of any governing policy in the same way as the condition of success of Hungarian foreign politics is the real secure political goal. Funda- mentally the all-time leadership has to be aware of the international circumstances in which the country lies, of the changes undergoing in the security environment and with the threats emerging from those changes, of the place the country takes in the international structure, and of its economic and political realities. The country has to find its place and tasks within the system of allies, and as a result, it should be in the possession of adequate tools to face the challenges. This set of assignments will appear when defining the duties of the national security services and the law enforcement organs, as their main role is to protect Hungary's independence, law and order and to provide the decision makers with the necessary infor- mation. On the one hand it manifests itself in the protection of the country from the outer threats, on the other hand it helps handling those inner conflicts which have a distorting effect on the functioning of the state and on the lives of its citizens. Though the national security domain is not in the possession of an individual strategic document, - its creation has been on the agenda for the past 25 years but there has been no consent in accepting it and having it accepted, - the concept along which it acts can be derived from the previously mentioned legal documents. Consequently, the viewpoint represented by the government concerning the policy of renewing strategies is reflected in the national security domain.

6 In my opinion - though it is not the aim of this paper to analyze current policy issues - there are three areas

of the government's external policy which can influence the Hungarian margins of maneuver and the status of the country within the EU and the NATO and which have come up embracing the idea of national interests:

the role assigned to Russia, the immigration policy opposing the EU standpoint, and the newly defined Eastern opening policy. 
The three cycles drafted in this paper with the shifts of stress can be followed in the transformations of the national security domain as well.

With the end of the bipolar world order and with the end of the Cold War era the national security services also changed, aligning itself to the new international norms and the require- ments of the constitutional state.

Act X of 1990, on the Interim Regulation of the Authorization of the Special Tools and Methods of Secret Services, and Act 26/1990, referring to the interim regulation of the tasks to be supplied by the national security services, then Act 125 of 1995, on the National Secu- rity Services designed the new structures, the managing and verifying mechanisms remained in force until 2011, without being shaken by Hungary joining NATO and the EU.

The risk factors existing previously, but back then not part of the strategic category (ter- rorism and arms trade), had to be re-defined, whereas the really new challenges like in- ternational organized crime, migration, the economic, financial crises, ethnic and religious tensions, illegal drug trafficking, the limitations on key-importance natural resources and the possibility of attacks against the information systems - had to be recognized, defined and then raised to a strategic level, first enclosed and defined in the 2002 National Security Strategy Act. At the same time, there has emerged the need to develop a strategic system in Hungary which reflected the viewpoint and the requirements of the government towards the law enforcement organs for creating an indivisible security of the nation.

Turning into the second cycle was not as obvious as one can see in the case of the armed forces. The decision making systems, that is the organizational structure did not change, but the tasks were modified.

These changes can be linked to the changes in the technological environment mainly, as they emerged from Hungarian membership in the international integration systems, charac- terized by an enhanced demand for high priority news materials and thirst for information. The information technological domain, the media, electronic communication and mobility starting at the beginning of the century and even nowadays - have gone through enormous changes. There was a time when the base of national security tasks and skills was laid down on the technical level. There has been a need to follow the changes of the technical environ- ment and to develop forward pointing developmental strategies ever since. [16: 226] A new objective was for the services to enter the international zone, which meant to detect and keep away the threats against the Hungarian forces and specialists in crisis management and peace keeping operations, as well as to start new forms of cooperation with civilian and national security organs of the allied countries and with NATO and EU intelligence and counter-in- telligence systems.

The significant changes concerning the national security domain arrived in the third cy- cle, but they became tangible only with the orders enforced in 2010, which re-drafted the institutional structure of the national security system. The management and direction of the unitary civilian national security domain - from which the Ministry of the Interior had been excluded by legal and political warranties - was re-defined along a new concept. The minister of the Interior has been the owner of the governing power over the National Security Special Service and the Constitution Protection Office (until 2010 named National Security Office) since 2011. In 2010 the minister of Foreign Affairs led the Information Office through his under-secretary; from 2010 the prime minister managed it through his undersecretary. With the armed forces the person in charge was and has ever been the Ministry of Defense, before 
and after unification. The government re-regulated the working National Security Cabinet and as a support, it created the National Security Workgroup.

The changes listed above have brought along novelties in terms of tasks, and at the same time other issues have come up, like the problems of networks and information-security, as the essential questions of the $21^{\text {st }}$ century, which need to be mentioned. At its center we need to put the ability to resist the attacks against the Internet information systems, the repression of information criminality and the internal and international cyber protection.

We have to mention the two events of consternation related to our topic, the WikiLeaks scandal in which several thousand diplomatic telegraphs and external affairs documents were aired; and the Edward Snowden case in which the US National Security Agency (NSA) data collection methods were unveiled, at the center of which was the telephone and Internet mass data scrutiny.

The implications on national security of the incidents above are unquestionable; in relation to Hungary there are three aspects of analysis: how can one guarantee discretion, what at- tempts have been made, or might have been made to observe the influence of foreign economic or intelligence interest groups on Hungarian public life, and what political, external and moral implications do the incidents have upon Hungarian-US and Hungarian-EU ally relations.

With globalization, technical development, the challenges of the information society, with the threats approaching from cyber space and with the unexpected events of our age, there has been a desire to satisfy the needs of society, where the need to satisfy the demands for national security on behalf of society will be a valued asset. [5: 20] Consequently, the task of the strategy will be the outlining of a vision, in other words, the ideological goals. The vision for the future defines the margins that have to be taken into account when setting priorities, and which has to be devised in such a manner that it reflects the prospective actions of response to the identified acts of threats which go far beyond the traditional military and civilian, external and internal, national and regional borders. [17: 93]

The projection of the national security domain, which is part of the strategic culture, and at the same time a central element of the national security system of values, serves the secu- rity and defense of the country by employing open, closed, secret intelligence, by collecting, analyzing, processing, utilizing and prognosticating information. In my opinion the future activities can be guaranteed if all personnel identify with the vision of the future which stands at the base of the concrete activity of service, and which is a vocation as described in the national security strategy and contains the following elements:

- the aspects of the forming stages of the country's internal and external threats both real time and in the course of time;

- identification of contingencies at a global, regional and internal level;

- the reality based prognosis of the changes in the region and the probable scenarios for managing the events;

- an inventory of the tasks and duties originating in the membership of an international organization and its national security aspects;

- the need to establish a system of relationships with non-governmental organization (NGO) actors, multinational and transnational companies, given their growing areas of influence and interest asserting activities;

- the positive and negative aspects of the new Hungarian foreign policy vision in terms of international assertion of interests and of transformation of security policy; 
- the analysis and prognosis of the frame conditions of the security of the economy, the sustainable growth;

- the possibilities of changes of the internal security challenges which can be attached to global trends, or inner processes, be they political, economic, environmental or social, which expand to the raising of the level of crime prevention and criminal intelligence;

- the deepening of the national security tasks concerning critical infrastructure defense in relation to the principle of "overall danger", highlighting the security of information;

- the promotion of the further deepening of the integration processes, especially strength- ening the European identity and promoting the common internal and external security policy, in which a special role is assigned to the European External Action Service (SITCEN, Joint Situation Center);

- diagnosing and devising plans for decreasing the threats against Hungarian corps and specialists operating abroad as well as Hungarians in crisis management and peace- keeping operations;

- opening towards new areas whose set of problems has an effect on the national secu- rity such as producing trends concerning the energy security or obtaining information which help keep the country's fuel supply on a stable level;

- keeping an inventory of the other organs which cooperate with the national security organs with special regard to the agents' system of interests and exceptional tasks;

- strengthening the relationship with the civilian populations and a clearer relationship with the open public;

- broadening cooperation with other branches in the process of crisis management;

- devising more effective operation plans to avoid parallelisms and strengthen organization potential;

- the re-definition of the intelligence and counter-intelligence tasks in the light of the security challenges of the $21^{\text {st }}$ century, whose first component is the relationship to the private secret services as such and the second is the integration of the novelties appear- ing while applying instruments and techniques and devising the legal background for all those above;

- adequate response given to the challenges of the social information and the information technology revolution ;

- the preparation for the information warfare in terms of its national security aspects, the prevention, management and declining of the risk factors and events concerning the information security;

- producing knowledge-surpluses in the domain of information technology by develop- ing coordinated analyzingevaluating skills and by adequately processing data existing at our disposal;

- the strengthening of the human resources, motivating the personnel and facilitating the decrease of fluctuation and quitting;

- enhancing the prestige of national security work. 


\section{Summary}

The real base for getting to know the future is the utilization of knowledge obtained by ex-perience, and the base of the preparation is professionally driven common thinking. One key question of planning is what has changed and what has not and what balance should be cre- ated between the existing skills and the expected threats, taking into consideration national interests and values.

Global-regional trends in relations are transforming in the $21^{\text {st }}$ century. The effect of these changes have been felt in the development of the political culture whose changes after the democratic turn gave the basis of a new strategic system and strategic culture. Some of the experts say the process is not yet balanced and not yet finished.

Presently, I believe, new opportunities have emerged due to the changes in world politics which have been highlighted in this paper from a national security aspect. We certainly can- not foresee whether the new ideas will stand firm among the challenges of the global world, whether they will be accepted or rejected in the light of our relationship with our allies, or how far will the new ideas fit the direction of changes of the global field of force.

Change is perpetual, but the tempo of the changes is not, and the three cycles of changes of the last 25 years drafted in this paper exemplify that. It is a time of globalization, in which instability is the most widely used notion and in which the unexpected events have speeded up. The domain of national security has a complex task of reacting, preventing, unveiling the reason elements, stating relations in a way to be usefully built on a real value and interest system in military, economic, technical, scientific and other areas, including the coalition commitments.

\section{References}

[1] PALÁNKAI T.: Nemzet és globalizáció. Magyar Tudomány, 1704 (2009), 441-459. www. matud.iif.hu/2009/09apr/07.htm (downloaded: 2101 2014)

[2] CSABA G.: A külpolitikai prognosztika elmélete és gyakorlata a változások korában. Külpolitika, II 3-4 (1996), 36-73.

[3] BEAUFRE, A.: Introduction a la stratégie. Paris: Librairie Armand Collin, 1963.

[4] HUNTINGTON, S. P.: A civilizációk összecsapása és a világrend átalakulása. Budapest: Európa Könyvkiadó, 1999.

[5] JÁVOR E.: A biztonsági stratégia kidolgozása során érvényesítendő elvek és módszerek. Hadtudomány, X 2 (2000), 20-27.

[6] KOROMPAI A.: Regionális stratégiák jövőkutatási megalapozása. In. NEMES NAGY J. (Ed.), Regionális Tudományi Tanulmányok. Budapest: ELTE RFT, 1995. http://geogr.elte.hu/ REF/REF_Kiadvanyok/REF_RTT_01/REF-RTT1.htm (downloaded: 2301 2015)

[7] SNYDER, J.: The Soviet Strategic Culture: Implications for Limited Nuclear Operations. Santa Monica: Rand, 1977.

[8] EICHLER, J.: Bezpečnostnía strategická kultura USA v letech 2001-2008. Mezynárodní Vztahy, 2 (2010), 48-70. https://mv.iir.cz/article/view/365/371 downloaded: 0409 2014) [9] LONGHURST, K. A.:

Strategic Culture: The Key to Understanding German Security Policy? Birmingham: Birmingham University, 2000. 
[10] GARIUP, M.: European Security Culture. Language, Theory, Policy. Farnham and Burlington: Ashgate Publishing, 2009.

[11] European Security Strategy. A Secure Europe in a Better World. Brussels, 12 December 2003.

[12] SIEDSCHLAG, A.: Strategische Kulturanalyse: Deutschland, Frankreich und die Transformation der NATO. In. SIEDSCHLAG, A. (Ed.), Methoden der sicherheitspolitischen Analyse. Wiesbaden: VS Verlag für Sozialwissenschaften, 2006.

21-48. http://link.springer.com/chapter/10.1007\%2F978-3-531-90229-6_2\#page-1 (downloaded: 0509 2014) DOI: https://doi.org/10.1007/978-3-531-90229-6_2

[13] Magyarország külkapcsolati stratégiája. www.kulugyminiszterium.hu/NR/ rdonlyres/7BA1F37C3370-431B-B9B1-F9FF3AF9F282/0/hu_kulkapcs_strat.pdf (downloaded: 2801 2015)

[14] SZENES Z.: Magyar haderöreform és az iraki magyar szerepvállalás. http://archiv. xxiszazadintezet.hu/rendezvenyek/szenes_zoltan_magyar_haderoref/szenes_zoltan_magyar_haderoref.html (downloaded: 2501 2015)

[15] KÜLÜGYMINISZTÉRIUM: Magyar külpolitika az uniós elnökség után. Budapest: KÜM, 2011. http://eu.kormany.hu/download/4/c6/20000/kulpolitikai_strategia_20111219.pdf (downloaded: 2501 2015)

[16] DOBÁK I., KOVÁCS Z.: Új technológiák hatása a hírszerzésre. In. DOBÁK I. (szerk.), Nemzetbiztonság általános elmélete. Budapest: Nemzeti Közszolgálati Egyetem, Nemzetbiztonsági Intézet, 2013. 206-220. (Egyetemi jegyzet)

[17] RAJNAI Z., FREGAN B.: Un portrait militaire au reflet de l'insurrection hongroise. Orients, 10 (2013), 93-96. 